\title{
SUCCESSFUL USE OF DANTROLENE SODIUM IN HUMAN MALIGNANT HYPERTHERMIA SYNDROME: A CASE REPORT
}

\author{
Clifford M. Friesen, Jay B. Brodsky and Michael F. Dillingham
}

SINCE THE ORIGINAL DESCRIPTION of the malignant hyperthermia syndrome (MHS)' numerous treatment modalities have been advocated, but the mortality remains high. Recently, dantrolene sodium has been shown to be effective in the, treatment of malignant hypertherma in swine. ${ }^{2.3}$ We wish to present a case in which dantrolene was used in the successful intraoperative treatment of the syndrome in man, and then used again prophylactically three months later before operation in the same patient.

\section{CASE REPORT}

A 28-year-old, $77 \mathrm{~kg}$, athletic male (ASA status 2) was scheduled for arthroscopy of an injured knee. His medical history was significant for labile essential hypertension and a cardiac murmur which had been labelled "innocent". The patient had undergone a tonsillectomy under general anaesthesia at six years of age without difficulty. There was no family history of anaesthetic complications or sudden death. He took no medications and denied drug allergies.

On admission to hospital his blood pressure was $160 / 90 \mathrm{~mm} \mathrm{Hg}$. There was a grade ii/vi systolic murmur, best heard at the upper left sternal border. The rest of the physical examination was within normal limits. He was extremely anxious about the proposed operation and anaesthesia.

On the morning of the operation he was premedicated with meperidine $75 \mathrm{mg}$ intramuscularly. Anaesthesia was induced with intravenous sodium thiopentone $300 \mathrm{mg}$. Halothane, nitrous oxide, and oxygen were delivered by mask to the spontaneously breathing patient. After 10 minutes, succinylcholine $20 \mathrm{mg}$ was administered intravenously. Because of inadequate relaxation, a further $100 \mathrm{mg}$ of succinylcholine was given. There were no muscle fasciculations with either dose. Relaxation was poor but the trachea was

Clifford M. Friesen, M.D., Resident in Anaesthesia; Jay B. Brodsky, M.D., Assistant Professor, Anaesthesia; Michael F. Dillingham. M.D. Assistant Professor of Surgery (Orthopaedics). Stanford University School of Medicine, Stanford, California 94305, U.S.A intubated without difficulty. Respiration was not assisted.

Forty-five minutes after induction the heart rate increased suddenly to 150 beats per minute and blood pressure rose to $200 / 100 \mathrm{~mm} \mathrm{Hg}$. The halothane concentration was initially increased, but was immediately discontinued when the patient developed multifocal premature ventricular beats. Lidocaine $100 \mathrm{mg}$ and phentolamine $10 \mathrm{mg}$ were administered intravenously. The premature ventricular beats disappeared, but tachycardia persisted. At this time the nasopharyngeal temperature was noted to have risen to $38^{\circ} \mathrm{C}$ from an initial $37.2^{\circ} \mathrm{C}$. The soda lime cannister and rubber tubing were extremely hot. A rectal temperature probe was placed and an initial reading of $38.5^{\circ} \mathrm{C}$ waś recorded. Malignant hyperthermia protocol was instituted. This consisted of iced intravenous solution, surface cooling with ice, administration of chlorpromazine and ventilation with a nonrebreathing circuit. Initial arterial blood gases showed $\mathrm{cH}^{+} 67.71 \mathrm{nmol} / 1(\mathrm{pH} 7.17), \mathrm{Paco}_{2}$ $9.44 \mathrm{kPa}$ ( $7 \mid$ torr), $\mathrm{Pa}_{\mathrm{O}_{2}} 20.48 \mathrm{kPa}$ (154 torr) and $\mathrm{HCO}_{3}-23 \mathrm{mmol} / \mathrm{I}$ after vigorous manual hyperventilation with 100 per cent oxygen. Dantrolene sodium was administered by rapid intravenous infusion. The patient's temperature decreased from a high of $39.4^{\circ} \mathrm{C}$ five minutes after dantrolene had been started to $36.5^{\circ} \mathrm{C}$ ten minutes later. A total of $250 \mathrm{mg}$ of dantrolene was given. The trachea was extubated and the patient was taken to the Intensive Care Unit for observation. He had elevation of temperature to $38^{\circ} \mathrm{C}$ for 24 hours postoperatively, but otherwise made an uneventful recovery. He was discharged five days later. On the fifth postoperative day his serum creatine phosphokinase (CPK) was 5260 units (normal 15-90 units).

The patient was readmitted three months later for a removal of a torn medial meniscus which had been diagnosed during the original arthroscopy. Preoperative serum CPK was 250 units. He was given dantrolene $300 \mathrm{mg}$ by mouth five hours before the operation. He experienced dizziness and nausea following this dose, so the subsequent oral dose was reduced to $150 \mathrm{mg}$ one hour before 
operation. Innovar* $2 \mathrm{ml}$ was given intravenously after the second oral dose of dantrolene. On arrival in the operating room, his blood pressure was $160 / 100 \mathrm{mg} \mathrm{Hg}$ and the heart rate was 80 per minute and regular.

A subarachnoid block was done with tetracaine $10 \mathrm{mg}$ and analgesia to the level of $T_{10}$ was achieved. The patient was sedated with diazepam $10 \mathrm{mg}$ intravenously. The rectal temperature rose $0.5^{\circ} \mathrm{C}$ in the course of the operation. Systolic blood pressure ranged between 130 and $160 \mathrm{~mm} \mathrm{Hg}$ and heart rate between 60 and 90 beats per minute. None of the classical signs of malignant hyperthermia appeared. He made an uneventful recovery and was discharged three days later.

\section{Discussion}

Dantrolene sodium is a hydantoin derivative, the use of which has been limited to the relief of spasticity associated with diseases such as multiple sclerosis, cerebral palsy, and spinal cord injuries. ${ }^{4}$ Its site of action is distal to the neuromuscular junction at the sarcoplasmic reticulum. Dantrolene prevents the release of $\mathrm{Ca}^{++}$into the sarcoplasm and thus prevents muscle contraction. ${ }^{s}$ The drug acts on skeletal muscle. There is no effect on cardiac muscle and smooth muscle is only 25 per cent as sensitive as skeletal muscle.

Dantrolene sodium has been used successfully in doses of $7.5 \mathrm{mg} \mathrm{kg}^{-1}$ intravenously to treat malignant hyperthermia in genetically susceptible swine. ${ }^{2,3}$. It has also been useful prophylactically in doses of $5 \mathrm{mg} \cdot \mathrm{kg}^{-1}$ by mouth the day before and four hours before anaesthesia to prevent malignant hyperthermia in swine. ${ }^{6}$

There have been ancedotal references to the use of dantrolene sodium in the treatment of malignant hyperthermia, but we are unaware of any published case reports of its use in man. Its use in man has been limited by lack of information on appropriate dosages. Extrapolations from animal studies indicate that the intravenous dose should be approximately $10 \mathrm{mg} \cdot \mathrm{kg}^{-1}$. We used only $3 \mathrm{mg} \cdot \mathrm{kg}^{-1}$ in our patient because his temperature fell to $36.5^{\circ} \mathrm{C}$ after $250 \mathrm{mg}$ had been given. The oral dosage of dantrolene for prophylaxis against malignant hyperthermia must also be determined empirically from animal studies. We had planned to use $10 \mathrm{mg} \cdot \mathrm{kg}^{-1}$ in two divided

*Innovar * (fentany $10.05 \mathrm{mg}+$ droperidol $2.5 \mathrm{mg} / \mathrm{ml}$ McNeil Laboratories, Inc., Fort Washington, PA 19031. doses but we limited the second dose because of the side effects our patient experienced. Common side effects are drowsiness, dizziness, nervousness, nausea and vomiting and a feeling of inebriation. Theoretically, patients receiving very large doses of dantrolene may also need assisted or controlled ventilation, since the drug is a muscle relaxant.

Dantrolene is available only in the powdered form. A solution is prepared by mixing dantrolene $300 \mathrm{mg}$, mannitol $26.64 \mathrm{~g}, \mathrm{NaOH} 48 \mathrm{mg}$. and distilled water to make $600 \mathrm{ml}$. Thirty min. utes of continuous stirring is needed to dissolve the dantrolene. Because of the difficulty in preparing this solution, and because during acute malignant hyperthermia the need for dantrolene is immediate, we keep several previously prepared bottles available in our operating room refrigerator for emergency use. We were thus able to begin dantrolene therapy very soon after the diagnosis of malignant hyperthermia was made. The early recognition and treatment probably accounted for the complete recovery of our patient without sequelae.

\section{SUMMARY}

We present a case of malignant hyperthermia in which successful management included the intravenous use of dantrolene sodium. A subsequent operation under spinal anaesthesia with oral dantrolene prophylaxis did not lead to de. velopment of malignant hyperthermia. Since this syndrome is rare during regional anaesthesia. the role of prophylactic oral dantrolene in preventing the redevelopment of malignant hyperthermia in our patient is open to question.

\section{Résumé}

Chez l'homme, on utilise le dantrolène sodique pour le traitement de la spasficité chronique. Sur l'animal expérimental, on a déjà démontré l'efficacité du traitement préventif au dantrolène dans le prévention du syndrome d'hyperthermie maligne. Pour le porc susceptible, une dose de $5 \mathrm{mg} \cdot \mathrm{kg}^{-1}$ suffit à prévenir l'apparition du syndrome alors que la dose de $7.5 \mathrm{mg} \cdot \mathrm{kg}^{-1}$ en modifie favorablement l'évolution une fois la crise établie. La littérature médicale contient plusieurs références sur l'emploi du dantrolène dans l'hyperthermie maligne, mais l'observation rapportè ici mentionne pour la première fois une réussite thérapeutique réalisée par ce médica. ment. Avant une opération subséquente sous 
anesthésie rachidienne, le dantrolène sodique fut aussi administré dans un but prophylactique. Comme l'hyperthermie maligne survient rarement au cours de l'anesthésie rachidienne, il est difficile de conclure à l'efficacité du médicament dans la prévention d'une deuxième crise chez ce malade.

\section{REFERENCES}

1. Denborovgh, M.A. \& Lovell, R.R.H. Anesthetic deaths in a family. Lancet 2:45 (1960).

2. Harrison, G.G. Control of malignant hyperpyrexic syndrome in MHS swine by dantrolene sodium. Br. J. Anaesth. 47:62 (1975)
3. Gronert, G.A., MILDE, J.H. \& Theye, R.A Dantrolene in porcine malignant hyperthermia. Anesthesiology 44: 488 (1976).

4. DYKES, M.H.M. Evaluation of a muscle relaxant: dantrolene sodium (Dantrium). J.A.M.A. 231: 862 (1975).

5. Ellis, K.O., Butterfield, J.L., Wessels, F.L. \& CARPENTER, J.F. A comparison of skeletal, cardiac, and smooth muscle actions of dantrolene sodium - a skeletal muscle relaxant. Arch. Int. Pharmacodyn. 224: 118 (1976).

6. HARRISON, G.G. The prophylaxis of malignant hyperthermia by oral dantrolene sodium in swine. Br. J. Anaesth. 49: 315 (1977). 